\title{
MUSLIM POPULATION IN THE SIBERIAN CITIES ACCORDING TO THE CENSUS OF 1897
}

\author{
Elena A. Brukhanova ${ }^{1} \&$ Natalya V. Nezhentseva ${ }^{2} \&$ Oksana I. Chekryzhova $^{3}$ \\ Altai State University. Barnaul, Russia
}

\begin{abstract}
Processes of urbanization and modernization created preconditions for qualitative changes in the demographic, social and professional structure of the cities, as well as for the formation of specific socio-professional groups. Meanwhile the active region development contributed to the individual ethno-confessional communities and diasporas formation and institutionalization in cities.

The main authors' task in to identify the ways of forming and the role of the Muslim community in the Siberian cities, based on the analysis of aggregated and nominative materials of the First General Census of the Russian Empire in 1897. The use of census lists makes for the specificity and novelty of the study. On the one hand, the data allow to obtain the most complete list of Muslim persons who were in the cities at the time of the census; on the other hand, it helps to undertake a comprehensive analysis of the demographic, social and occupational characteristics of the Muslim population.

We present the socio-demographic characteristics of Muslims who lived in Siberia at the late 19th century including the map of the Muslims' location in the counties, as well as their number and gender composition in the Siberian cities. The general portrait of the Muslim in the Siberian cities was shaped based on the aggregated data of the 1897 census. The information taken from the census lists made it possible to surmise on about the formation of the Muslim community in individual cities, and to characterize the Muslim society structure in the Tobolsk province cities.
\end{abstract}

The article is intended for specialists-historians, ethnographers, social anthropologists and a wide range of readers.

\section{Keywords}

Moslimism; Islam; the Census 1897; urban population; foreigners; Tatars; historical source; historical database; Siberia; Russian Empire

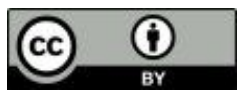

This work is licensed under a Creative Commons «Attribution» 4.0 International License

1 Email: elena[at]hist.asu.ru

2 Email: neshenzewan[at]mail.ru

3 Email: niigi[at]yandex.ru 


\section{МУСУЛЬМАНСКОЕ НАСЕЛЕНИЕ В ГОРОДАХ СИБИРИ: ПО МАТЕРИАЛАМ ПЕРЕПИСИ 1897 ГОДА}

Брюханова Елена Александровна ${ }^{1}$, Неженцева Наталья Владимировна ${ }^{2}$, Чекрыжова Оксана Ивановна ${ }^{3}$

Алтайский государственный университет. Барнаул, Россия

Аннотация

Урбанизационные и модернизационные процессы создали предпосылки для качественных изменений в демографической, социальной и профессиональной структуре городов, к формированию специфических социальнопрофессиональных групп. В то же время активное развитие региона способствовало образованию и институционализации отдельных этно-конфессиональных сообществ и диаспор в городах.

Основная задача статьи видится в выявлении путей формирования и роли мусульманского сообщества в городах Сибири на основе анализа агрегированных и номинативных материалов Первой всеобщей переписи населения Российской империи 1897 г. Особенностью и новизной исследования является привлечение в качестве основного источника переписных листов 1897 г. по городам Тобольской губернии, сведения которых позволяют, с одной стороны, получить наиболее полный перечень лиц, исповедующих мусульманство и находящихся на момент переписи в городах, а во-вторых, провести комплексный анализ демографических, социальных и профессиональных характеристик мусульманского населения.

В статье рассмотрены социально-демографические характеристики мусульман, проживавших в Сибири в конце XIX в., представлена карта, отражающая расселение мусульман по уездам, а также их численность и гендерный состав в городах Сибири. На основе агрегированных данных переписи 1897 г. был сформирован общий портрет мусульманина-горожанина сибирского региона. Сведения переписных листов позволили сделать выводы о сформированности мусульманской общины в отдельных городах, дать характеристику структуре мусульманского общества в городах Тобольской губернии. Статья предназначена как для специалистов - историков, этнографов, социальных антропологов, - так и для широкого круга читателей.

\section{Ключевые слова}

Мусульманство; ислам; перепись 1897; городское население; инородцы; татары; исторический источник; историческая база данных; Сибирь; Российская империя

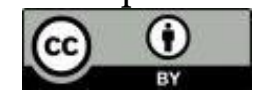

Это произведение доступно по дицензии Creative Commons «Attribution» («Атрибуция») 4.0 Всемирная

1 Email: elena[at]hist.asu.ru

2 Email: neshenzewan[at]mail.ru

3 Email: niigi[at]yandex.ru 


\section{ВВЕДЕНИЕ}

Город является одним из интересных и неоднозначных объектов исторических, социокультурных, экономических и других исследований, в том числе и в контексте изучения этно-конфессиональных особенностей региона.

Период конца XIX - начала XX в. рассматривается как отдельный этап развития городов Российской империи, обусловленный экономическим ростом и расширением транспортных путей (Миронов, 2012). В сибирском регионе в этот период также происходили значительные изменения, в том числе в сети городских поселений и их структуре. Особенности развития сибирских городов конца XIX в. объясняются исследователями целым рядом факторов: строительством Транссибирской магистрали, добровольными и принудительными миграциями, военным и политическим значением административных центров (Скубневский \& Гончаров, 2014). Происходящие процессы стали стимулами к количественным и качественным изменениям в структуре городского населения, способствовали формированию социальнопрофессиональных групп. Еще одной тенденцией развития региона в рассматриваемый период стало институциональное оформление этно-конфессиональных сообществ и диаспор в городах, например, еврейских, польских и немецких общин в Западной Сибири (Шайдуров, 2014; Shaidurov 2017; Shaidurov 2018), татарских общин на Дальнем Востоке (Старостин, 2019). В таком контексте изучение особенностей образования мусульманской диаспоры в городской среде сибирского региона представляется актуальным.

Целью статьи является определение путей формирования и роли мусульманского сообщества в городах Сибири на основе анализа агрегированных и номинативных материалов Первой всеобщей переписи населения Российской империи 1897 г. Стоит отметить, что первичные материалы переписи содержат уникальные сведения по городам Тобольской губернии и позволяют решить ряд исследовательских задач. Так, специфика заполнения переписных листов предусматривала составление поименного списка мусульман, как постоянно, так и временно проживавших в городах на начало 1897 г., а широкая программа переписи обеспечила возможность проведения комплексного анализа выявленного сообщества по различным социально-демографическим характеристикам. В целом, привлечение переписных листов к изучению мусульманского населения в городах Сибири представляется новым и оригинальным подходом. 


\section{ИСТОЧНИКИ И ИССЛЕДОВАНИЯ}

Первая всеобщая перепись населения 1897 г. стала крупнейшим и наиболее комплексным статистическим исследованием Российской империи конца XIX - начала XX в. Для Сибири материалы переписи, опубликованные в восьми томах по губерниям (Первая, 1905), Общем своде по империи (Общий свод, 1905), а также специальных разработках (Распределение, 1905), стали уникальным источником данных об этническом, конфессиональном, демографическом, социальном и профессиональном составе населения всех округов, городов и административных центров. Стоит отметить, что агрегированные данные переписи 1897 г. уже привлекались для изучения мусульманского населения отдельных регионов Сибири (Кабульдинов, 2001; Гостюшева \& Должиков, 2019; Старостин, 2019), а также других территорий, например, Пермской (Бобицкий, 2017), Казанской (Загидуллин, 2000) и Уфимской губерний (Ахтямова, 2016). Во многих работах использовались сведения не только о вероисповедании, но об этнической принадлежности на основе родного языка. Такой подход связан с особенностями разработки и унификации данных переписи. Так, распределение населения по вероисповеданию представлено только в трех таблица и комбинировано со сведениями по родному языку, грамотности и возрастам, тогда как распределение по родному языку встречается в пяти таблицах и сочетается с данными о грамотности, возрастам, семейному положению, физическим недостаткам, занятости, сословиям и состояниям (Первая, 1905). Таким образом, сочетание сведений о вероисповедании и родном языке позволяет получить представительный набор данных о мусульманском населении региона.

Вместе с тем, несмотря на универсальность агрегированных данных, в некоторых трудах указывалось на ошибки в статистических таблицах результатов переписи 1897 г. Чаще всего замечания касались сведений по родному языку и по занятости (Брюханова, 2019, с. 161). Так, 3.Е. Кабульдинов, сравнив агрегированные и персональные данные о занятости казахов Тюкалинского и Тарского уездов Тобольской губернии, пришел к выводу об ошибочной записи о причислении казахов Тобольской губернии к земледельцам, т.к. большинство хозяйств в переписных листах были скотоводческими (Кабульдинов, 2001, сс. 183-185).

Переписные листы Первой всеобщей переписи населения представляют собой уникальный исторический источник, содержащий персональные сведения о жителях по ряду показателей, таким как пол, возраст, сословие, место рождения, приписки, проживания, грамот- 
ность, основное и побочное занятия. К сожалению, переписные листы сохранились лишь по отдельным сибирским городам. Наиболее репрезентативный комплекс переписных листов сохранился по 8 из 10 городов Тобольской губернии в Государственном бюджетном учреждении Тюменской области «Государственный архив в г. Тобольске» (ГБУТО ГАТ. 1897). По сохранившимся материалам авторами статьи была создана база данных «Население городов Сибири на рубеже XIX-XX вв.: по материалам Первой всеобщей переписи населения Российской империи 1897 г.», а также одноименная информационная система (Население, 2021). База данных является источникоориентрованной и позволяет получить все сведения из источника. Первичные материалы переписи 1897 г. использовались как для рассмотрения отдельных этнических групп (Патканов, 1912; Машарипова, 2013; Кабульдинов, 2001), так и для анализа социальной и профессиональной структуры городского населения (Bryukhanova, \& Vladimirov, 2017). В целом сведения переписных листов позволяют существенно дополнить статистические данные переписи 1897 г, а также получить персонифицированную информацию по мусульманскому населению большинства городов Тобольской губернии.

Можно отметить различные подходы к изучению мусульманского населения Сибири. Так, П. К. Дашковский, А. П. Ярков, Ю. А. Лысенко анализировали конфессиональную политику Российской Империи в отношении мусульманских народов, играющих значительную роль в заселении и освоении малозаселенных территорий Западной и Восточной Сибири. Кроме того, рассматривалась активная миссионерская деятельность, проводившаяся с целью привлечения к православию мусульман (Дашковский, 2014, с. 94; Ярков, 2014, с. 132; Дашковский \& Шершнева, 2016, с. 94; Лысенко, 2010, c. 54). Отдельное внимание уделялось юридическому положение мусульманских общин. 3.Е. Кабульдинов отмечал, что основными нормативными документами, определяющими права мусульман, были «Устав о сибирских киргизах», «Положение об управлении инородцев» $(1892$ г.), «Свод учреждений и устав управления духовных дел иностранных исповеданий христианских и иноверных» (1896) (Кабульдинов, 2001, с. 64). Положение мусульманских общин на малозаселённых территориях корректировалось с учетом политики колонизации окраин Империи (Шерстова, 2005). Кроме того, можно выделить группу работ, посвященных этноконфессиональным группам отдельных сибирских городов, таких как Верхнеудинск (Перинов, 2009), Ишим (Ярков, 2012), Томск (Наумова, 2005), и регионов, например, Восточной Сибири (Старостин \& Павлинова, 2016) и Даль- 
него Востока (Старостин, 2019). Тем не менее, исследование, основанное на комплексном подходе и персонифицированных данных, позволит, на наш взгляд, расширить представления о мусульманском населении городов Сибири.

\section{МУСУЛЬМАНЕ ГОРОДОВ СИБИРИ ПО СТАТИСТИЧЕСКИМ МАТЕРИАЛАМ ПЕРЕПИСИ 1897 Г.}

Всего в Сибири по данным Первой всеобщей переписи 1897 г. проживало 126574 мусульман (72184 мужчин, 54388 женщин), что составило около $1 \%$ от всех мусульман Российской империи. Мусульмане составляли 2,2\% от всего населения Сибири и занимали 4 место по численности после православных (85,8\%), старообрядцев $(4,2 \%)$, буддистов и ламаистов $(4,3 \%)$.

\begin{tabular}{lcccc}
\hline В уездах & $\begin{array}{c}\text { \% от числа } \\
\text { жителей } \\
\text { уездов }\end{array}$ & В городах & $\begin{array}{c}\text { \% от числа } \\
\text { жителей } \\
\text { городов }\end{array}$ \\
\hline Амурская & 665 & 0,6 & 308 & 0,9 \\
Енисейская & 5027 & 0,9 & 1370 & 2,2 \\
Забайкальская & 3182 & 0,5 & 321 & 0,8 \\
Иркутская & 7599 & 1,5 & 1180 & 1,9 \\
Приморская & 1268 & 0,6 & 543 & 1,1 \\
Сахалин & 1843 & 6,6 & 702 & 8,2 \\
Тобольская & 64880 & 4,5 & 1877 & 2,1 \\
Томская & 40201 & 2,1 & 2225 & 1,7 \\
Якутская & 1909 & 0,7 & 668 & 7,3 \\
Сибирь & 126574 & 2,2 & 9194 & 1,9 \\
\hline
\end{tabular}

Таблица 1. Численность мусульман в губерниях Сибири (Общий свод, Т1., с. 267)

Table 1. Muslims populations in the provinces of Siberia (General vault, Vol. 1, p. 267)

Наибольшая численность мусульман была зарегистрирована переписью в Тобольской и Томской губерниях (Таблица 1). Стоит отметить, что некоторые авторы отмечали влияние «откачевок» казахов на численность этноконфессиональных групп указанных губерний (Кабульдинов, 2001, с. 4; Карих, 2014, сс. 59-60). Визуализация численности мусульман по уездам Сибири представлена на Рисунке 1, 
на котором видно, что наибольшее количество мусульман проживало в Тобольском (22 163 чел.), Тарском (14076 чел.), Тюменском (12 281) округах Тобольской губернии и Змеиногорском (14320 чел.) и Каинском (10141 чел.) округах Томской губернии (Первая, 1905).

Заметная доля мусульман на остове Сахалин, а также в городах Восточной Сибири и Дальнего Востока объясняется исследователями потоком ссыльнопоселенцев и каторжан (Константинова, 2007, с. 419). Этим аспектом объясняется и половозрастная диспропорция мусульманского населения (особенно в городах, где мужчины составляли 67\%) в сторону значительного преобладания мужчин среднего возраста (2040 лет). В отличие от ссыльных других вероисповеданий, часто следующих к местам ссылок вместе с семьями, среди мусульман такого практически не наблюдалось. По мнению В. П. Литвинова, высылка мусульман способствовала решению многих имперских проблем, существующих на национальных окраинах, и одновременно колонизации малонаселенных земель (Литвинов, 2015, с. 36).

Численность мусульман в городах Сибири является дискуссионным вопросом. Некоторые неточности встречаются при сопоставлении данных разных изданий результатов переписи. Например, в томе 1 Общего свода результатов переписи по Империи общее количество мусульман в городах составляет 9194 чел. (Общий свод, Т.1., с. 267), а в томе 2 Общего же свода в таблице 14 численность магометан в городах указана 8492 чел. (Общий свод, Т. 2., с. 126). Суммарное количество мусульман в сибирских городах, представленное в томах по губерниям, совпало с данными тома 1 (Первая, 1905). Сопоставление материалов переписи 1897 г. с Обзором Томской губернии за 1896 г. (Обзор, 1897, Приложение 1 к ведомости 3), в котором была указана численность мусульман в некоторых городах, также показало расхождение данных: для Барнаула, Каинска и Мариинска (265 чел., 120 чел., 103 чел. соответственно) данные переписи превышали показатели административного учета (145 чел., 53 чел., 87 чел.), тогда как для Томска сведения переписи показали на 1000 мусульман меньше, чем в Обзоре (1527 чел. и 2406 чел.). Принимая во внимание, что перепись проводилась единовременно и «на научных принципах», основу исследования составили статистические данные переписи 1897 г.. При этом следует учитывать и тот факт, что перепись проводилась зимой, когда численность городов менялась за счет сезонных мигрантов и переселенцев (Первая, Т. 78, 1905, с. 25). Численность и гендерная структура мусульман в городах Сибири по материалам переписи 1897 г. представлена на Рисунке 1. 


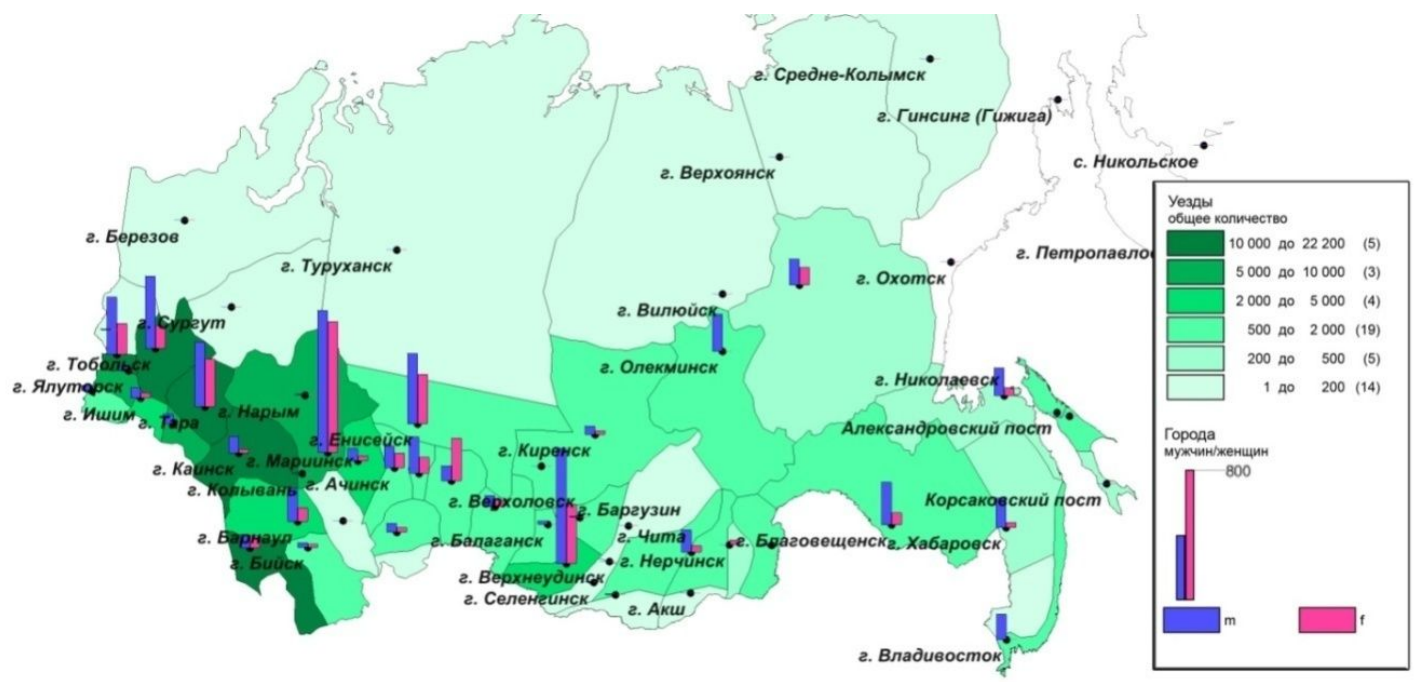

Рисунок 1. Численность мусульман в уездах и городах Сибири по материалам переписи 1897 г.

Figure 1. Muslims populations in the Siberian counties and cities, based on the 1897 census

Наиболее многочисленные мусульманские сообщества проживали в Томске, Иркутске, Енисейске, Таре, Тобольске и Тюмени. Заметную долю в среде городского населения мусульмане составляли в г. Олекминске Якутской губернии и г. Тара Тобольской губернии (Таблица 2).

В этническом отношении большинство мусульман $(92,6 \%)$ являлись представителями турецко-татарской языковой группы (Общий свод, Т. II, с. 126). Это обстоятельство позволяет проследить занятость большей части мусульманского населения. Так, наиболее распространенными сферами деятельности татар были торговля, извоз, служба в вооруженных силах и работа в сфере обслуживания, заметной была доля заключенных среди татарского населения. Существенно отличись по занятости татарского населения Приморская область и о. Сахалин, в первой из которых больше 93\% татар-мужчин были военнослужащими, а на втором 51\% татарского населения отбывали наказание, а $32 \%$ указали основное занятие как земледелие и, можно предположить, что являлись ссыльнопоселенцами. 
Журнал Фронтирных Исследований. 2021. No 4 | ISSN: 2500-0225

Этнические меньшинства в контактных зонах | Doi: https://doi.org/10.46539/jfs.v6i4.338

\begin{tabular}{|c|c|c|c|}
\hline & $\begin{array}{c}\text { Количество } \\
\text { жителей }\end{array}$ & $\begin{array}{l}\text { Количество } \\
\text { мусульман, } \\
\text { всего }\end{array}$ & $\begin{array}{c}\text { Доля мусульман } \\
\text { в городском } \\
\text { населении }\end{array}$ \\
\hline Томск & 52210 & 1527 & 2,9 \\
\hline Иркутск & 51673 & 973 & 1,9 \\
\hline Енисейск & 11406 & 671 & 5,9 \\
\hline Tapa & 7223 & 627 & 8,7 \\
\hline Тобольск & 20425 & 534 & 2,6 \\
\hline Тюмень & 29544 & 498 & 1,7 \\
\hline Олекминск & 1144 & 417 & 36,5 \\
\hline Благовещенск & 32834 & 308 & 0,9 \\
\hline Красноярск & 26699 & 296 & 1,1 \\
\hline Барнаул & 21073 & 265 & 1,3 \\
\hline Якутск & 6535 & 246 & 3,8 \\
\hline Ачинск & 6699 & 211 & 3,1 \\
\hline
\end{tabular}

Таблица 2. Города Сибири, в которых численность жителей-мусульман больше 200 чел. (Первая, 1905)

Table 2. Cities of Siberia with more than 200 Muslim inhabitants. (Pervaya, 1905)

Таким образом, агрегированные данные переписи 1897 г. позволили сформировать два портрета мусульманина-горожанина сибирского региона: первый - это молодой мужчина (18-30 лет), ссыльный татарин; второй - молодой мужчина (18-39 лет), татарин, занятый в традиционных для городов сферах таких, так торговля, извоз, обслуживание, либо служащий в вооруженных силах.

\section{МУСУЛЬМАНЕ В ГОРОДАХ ТОБОЛЬСКОЙ ГУБЕРНИИ ПО МАТЕРИАЛАМ ПЕРЕПИСНЫХ ЛИСТОВ ПЕРЕПИСИ 1897 Г.}

К маю 2020 г. база данных «Население городов Сибири на рубеже XIX-XX вв.: по материалам Первой всеобщей переписи населения Российской империи 1897 г.» содержала сведения о 1816 мусульман по городам Тобольск (571 чел.), Тара (642 чел.), Тюмень (390 чел.), Ишим (94 чел.), Тюкалинск (54 чел.), Курган (39 чел.), Ялуторовск (19 чел.) и Туринск (7 чел.). Некоторые расхождения с агрегированными данными объясняются несколькими факторами. Численность ниже, чем указанная в статистических таблицах, обусловлена тем, что база данных находится еще в стадии заполнения. Количество мусуль- 
манского населения выше, чем указано в изданиях переписи, связано с особенностями заполнения переписных листов, в частности в тюремных замках и каторжных тюрьмах. В соответствии со специальной инструкцией сведения о заключенных вносились в общие перечневые ведомости заранее (примерно за две недели), а затем проверялись и исправлялись «по состоянию» на 28 января (Инструкция, 1896, сс. 1-2), что привело к наличию вычеркнутых записей. Так, из 203 записей о мусульманах-заключенных тобольских тюрем 21 запись вычеркнута полностью, т.е. людей перевели в другие пенитенциарные учреждения или отправили на поселения.

По общим социально-демографическим показателям мусульманского населения в городах Тобольской губернии сведения переписных листов аналогичны опубликованным результатам переписи. В целом очевидна гендерная (Рисунок 2) и возрастная диспропорция в большинстве городов. Из всех мусульман, находившихся в момент переписи в городах Тобольской губернии, 70\% были мужчинами, из которых 48\% в возрасте от 18 до 40 лет; при этом в Тюкалинске (по выборке), Ялуторовске и Туринске женщин и детей перепись не зарегистрировала.

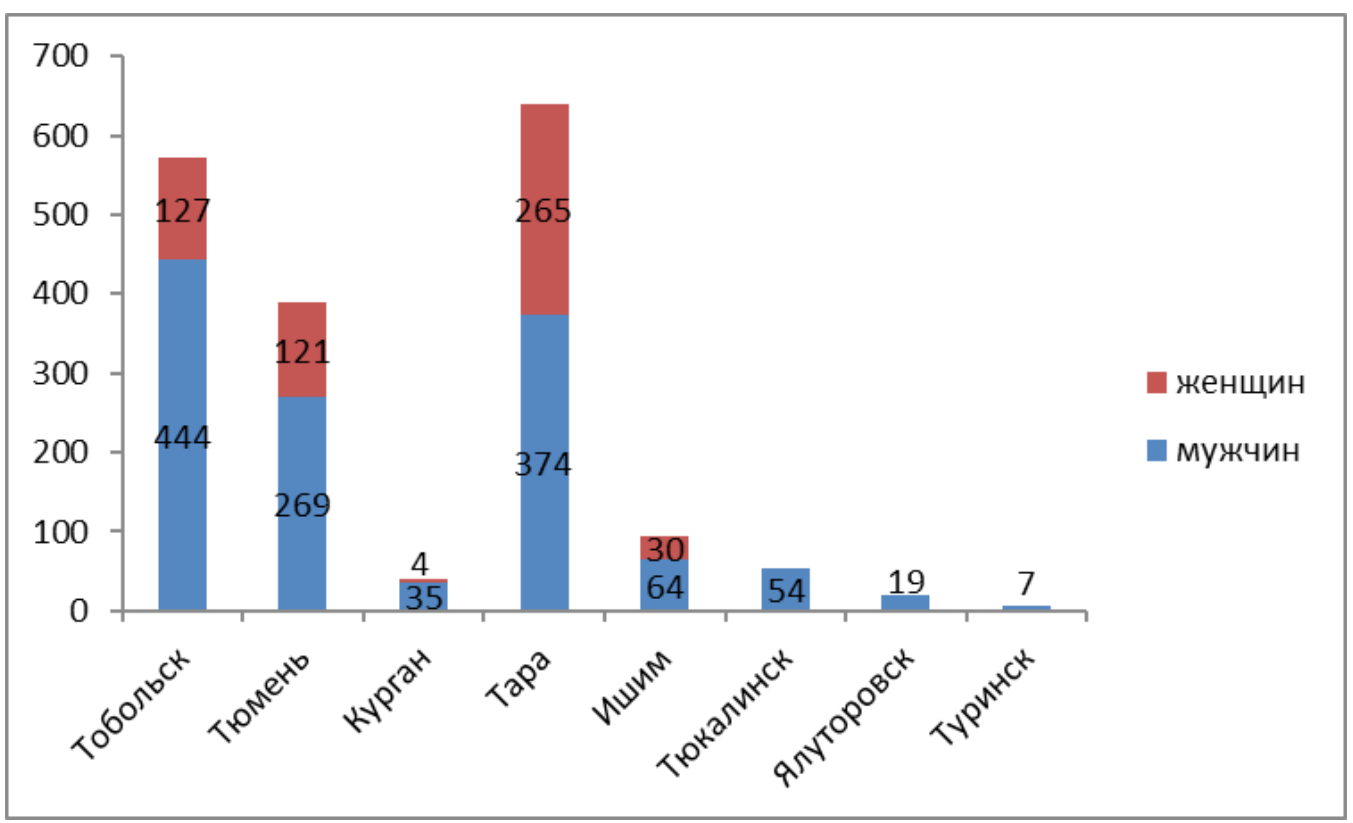

Рисунок 2. Гендерная структура мусульман в городах Тобольской губернии по материалам переписи 1897 г.

Figure 2. The gender structure of Muslims in towns in Tobolsk Province, according to the census of 1897 . 
Такая диспропорция обусловлена, во-первых, несением молодыми мусульманами-мужчинами старше 21 года военной службы в соответствии с «Уставом о воинской повинности» (1874 г.), во-вторых, наличием в Тобольской губернии тюрем разных категорий (каторжные, пересыльные тюрьмы, исправительные и арестантские отделения). Так, военнослужащие составляли 7\% (128 чел.), а заключенные $17 \%$ (311 чел.) от общей численности мусульман в городах Тобольской губернии. При этом в отдельных случаях указанные факторы имели ключевое значение в формировании мусульманского населения в городах: в Туринске - 100\%, в Ялуторовске - $68 \%$ мусульман были военнослужащими, в Тюкалинске 68,5\%, в Тобольске 35,5\% мусульман находились в тюремном замке.

Интересно отметить, что большинство мусульман, находившихся на военной службе или отбывающих наказание, в городах Тобольской губернии были выходцами из других регионов Российской империи, а также носителями более 20 языков. 62,5\% мусульман, несущих военную службу, были родом из Казанской губернии, 20,3\% - из Уфимской, Вятской и Пермской губерний, и 11,7\% были местными уроженцами (ГБУТО ГАТ. 1897е. Л.15, 36; ГБУТО ГАТ. 1897d. Л.31). Из 210 человек, исповедующих ислам и говорящих на сартском, персидском, черкесском, башкирском и других языках, кроме татарского, киргизского и русского, 196 были заключенными тобольских тюрем. Таким образом, военная служба и институт ссылки формировали этно-конфессиональное разнообразие во многих городах Тобольской губернии.

Несмотря на значимость рассмотренных факторов, всего в городах Тобольске, Тюмени, Таре, Кургане и Ишиме проживало $78 \%$ или 1412 мусульман, не связанных военной службой или ссылкой, из них $89 \%$ постоянно проживали в городах. Неким показателем сформированности мусульманского сообщества является наличие и количество семейных домохозяйств. Так, в Кургане проживало только 3 мусульманских семьи, в Ишиме - 11, в Тобольске - 36, Тюмени - 52, Tape - 109. Большинство городских мусульманских семей были немногочисленны (2-7 чел.), большие патриархальные семьи, в которых проживало несколько поколений, были зарегистрированы переписью только в Таре и Тобольске. В этих же городах находились мечети. Наиболее многочисленными были семьи Бекшиневых, Башировых, Саитовых, Айтыкиных, Рахматуллиных, Курмановых. В переписных листах также нашло отражение такое явление, возможное в магометанских семьях, как наличие нескольких жен. Например, две жены имели тобольский купец Тохтасын Айтмухаметов (52 года), 
представители тобольского рода Бекшеневых Мухамет (48 лет) и Авусагин (30 лет) (ГБУТО ГАТ. 1897а. Л.15, 36; ГБУТО ГАТ. 1897b. Л.2, 3), тобольский имам и мулла Шарыпов Шакир Абдул, тарский торговец Митридинов (42 года), содержатель земской станции Бухарского волостного правления Сеитов (50 лет) и крестьянин Уватской волости Тобольского уезда Ибрагим Шаги-Мартанов (38 лет).

Переписные листы позволяют получить представление о социальном составе мусульманского общества городов Тобольской губернии. Стоит отметить, что переписные листы отражают самоидентификацию личности, т.к. сведения записывались «со слов».

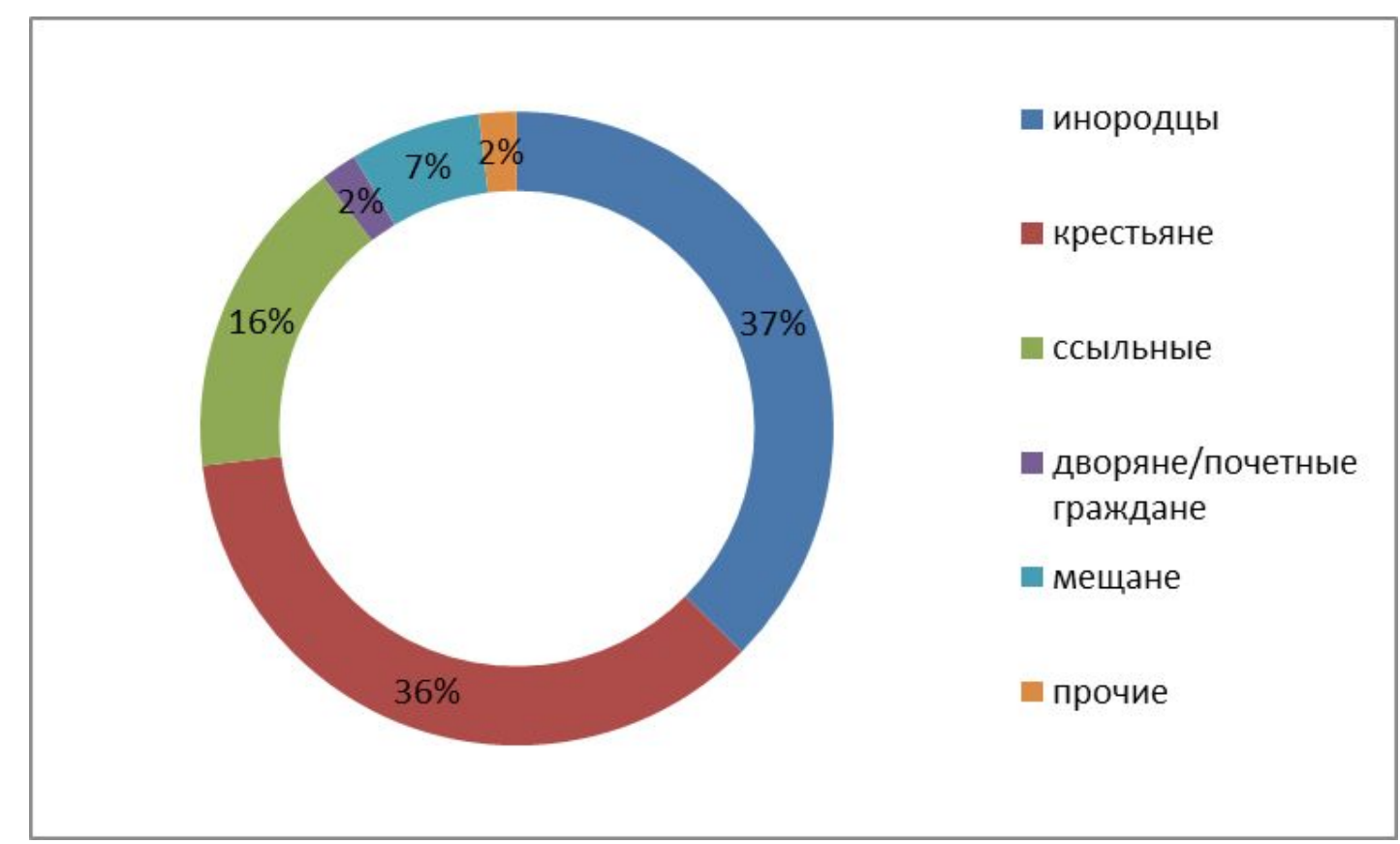

Рисунок 3. Распределение мусульман городов Тобольской губернии сословиям и социальным группам на основе данных переписных листов переписи 1897 г.

Figure 3. The distribution of Muslims in Tobolsk Province cities into estates and social groups, based on data from the census of 1897

На Рисунке 3 представлено распределение мусульман городов Тобольской губернии сословиям и социальным группам: 37\% (680 чел.) отнесли себя к инородцам (из них 304 чел. назвали себя представителями бухарских татар), 36,6\% (665 чел.) - к крестьянам, 15\% к различным категориям ссыльных. Кроме того, к дворянам отнесли себя 27 человек - представители рода Кульмаметьевых, проживающих в Тобольске (6 человек) и Тюмени (21 человек), - и 13 человек семьи 
Айтыкиных из г. Тары имели статус почетных граждан (ГБУТО ГАТ, 1897с. Л. 125). Интересно, что известные купцы 2 гильдии Айтмухаметовы, Айтыкины, Бекшеневы (Календарь, 1897, сс. 28, 33) указали свое состояние по происхождению, т.е. как инородцев.

Анализ данных переписных листов показал характерный для городов уровень занятости: в среднем доля самозанятых магометан в городах Тобольске, Ишиме, Тюмени, Кургане и Таре была 54\%. Исключение составила только Тара, в которой члены семьи составили 54,6\%. В целом сферы занятости мусульман также были традиционными для городского населения: торговля (12,9\%), работники и прислуга $(16,8 \%)$, извозный промысел $(3,8 \%)$ и ремесло $(6 \%)$. В сельском хозяйстве было занято 4\% мусульман, преимущественно в г. Тобольске (33 чел.), большинство из которых приехали в город на заработки из волостей Тобольского округа и проживали в постоялых дворах по улицам Береговая и Абрамовская. В Кургане 5 киргизов-кочевников из Акмолинского округа также приехали для сезонных заработков чернорабочими.

На основе агрегированных и персональных данных переписи 1897 г. можно сделать вывод о сформированности мусульманских сообществ как отдельных этноконфессиональных групп в городах Тобольск, Тара и Тюмень. Для магометанских обществ было характерно, с одной стороны, стремление к сохранению семейных традиций, религии и культуры, с другой - городской образ жизни и вовлеченность в экономику городов. В других городах путями увеличения численности мусульманского населения были миграционные процессы, пенитенциарная система и военная служба.

\section{ВЫВОДЫ}

Анализ материалов Первой всеобей переписи населения Российской империи 1897 г. показал, что можно выделить 4 группы мусульман в городах Сибири. Отдельную социальную группу составляли ссыльные различных категорий, в том числе заключенные каторжных, пересыльных тюрем в г. Тобольске, арестантских отделений других городов. Эта группа отличалась этнической «пестротой» и разнообразием губерний выхода мусульман (Средняя Азия, Кавказ, Европейская Россия). Следующая группа представлена, преимущественно, молодыми татарами-мусульманами, отбывающими военную службу. В городах Тобольской губернии срочные военнослужащиемусульмане были выходцами из Казанской, Уфимской и Пермской губерний. Мусульманские сообщества в городах Тобольске и Таре сформировали преимущественно «местные» инородцы - выходцы 
из бухарских татар, которые, с одной стороны, стремились сохранить традиции, с другой, были вовлечены в экономику города, что влияло, например, на размер и состав домохозяйств. Самую малочисленную группу составили крестьяне и инородцы, временно пребывающие в города для сезонных заработков. Стоит отметить, что для большинства мусульман-горожан была характерна традиционная для городского населения занятость: торговля, извоз, сфера обслуживания.

В целом, материалы переписи 1897 г. позволяют получить представление о социально-демографических и экономических особенностях мусульманского населения, сделать вывод о сформированности мусульманского сообщества в отдельных городах Сибири.

\section{БЛАГОДАРНОСТЬ}

Исследование выполнено за счет гранта Российского научного фонда, проект № 19-78-10020 «Урбанизационные процессы в Сибири на рубеже XIX-XX вв.: комплексный подход к анализу городского населения по материалам Первой всеобщей переписи населения Российской империи 1897 г.»

\section{Список литературы}

Bryukhanova, E., \& Vladimirov, V. (2017). Urban occupations in a siberian city (Tobolsk, 1897). Quaestio Rossica, 5(1), 56-73. doi: 10.15826/qr.2017.1.210

Shaidurov, V. (2017). German Industrial Enterprises in Western Siberia in the second half of the 19th century. Bylye Gody, 43(1), 162-168. doi: 10.13187/bg.2017.1.162

Shaidurov, V. N. (2018). The Polish community in Western Siberia: Adaption and integration features in the second half of the 19th century. Acta Histriae, 26(2), 641-660. doi: 10.19233/AH.2018.26

Бобицкий, А. В. (2017). Мусульмане Екатеринбургского уезда в материалах первой всеобщей переписи населения Российской империи 1897 г. Шаг в историческую науку, 25-27. Екатеринбург: Уральский государственный педагогический университет.

Брюханова, Е. А. (2019). Перепись 1897 г.: Обретение «утраченных» материалов и их предварительный анализ. Известия Уральского федерального университета. Серия 2, Гуманитарные науки, 21(3), 152-167. doi: 10.15826/izv2.2019.21.3.053

Брюханова, Е. А., Иванов, Д. Н., Неженцева, Н. В., \& Чекрыжова, О. И. (2021). Население городов Сибири на рубеже XIX-XX вв. По материалам Первой всероссийской переписи населения 1897 года. Извлечено от https:// person1897.histcensus.asu.ru/

Гостюшева, Е. М., \& Должиков, В. А. (2019). Конфессиональный состав населения Томской губернии по данным первой всероссийской переписи 1897 г. 
Вестник Томского государственного университета. История, (59), 12-19. doi: $10.17223 / 19988613 / 59 / 2$

Государственное бюджетное учреждение Тюменской области «Государственный архив в г. Тобольске». (1897а). Ф. И 417. Оn. 2. Д. 13.

Государственное бюджетное учреждение Тюменской области «Государственный архив в г. Тобольске». (1897b). Ф. И 417. On. 2. Д. 19.

Государственное бюджетное учреждение Тюменской области «Государственный архив в г. Тобольске». (1897с). Ф. И 417. Оп. 2. Д. 1932.

Государственное бюджетное учреждение Тюменской области «Государственный архив в г. Тобольске». (1897d). Ф. И 417. Оn. 2. Д. 2530.

Государственное бюджетное учреждение Тюменской области «Государственный архив в г. Тобольске». (1897е). Ф. И 417. On. 2. Д. 3660.

Дашковский, П. К. (Ред.). (2014). Религиозный ландшафт Западной Сибири и сопредельных регионов Центральной Азии. Барнаул: Издательство Алтайского государственного университета.

Дашковский, П. К., \& Шершнёва, Е. А. (2016). К вопросу о взаимоотношении Русской православной церкви и мусульман Западной Сибири во второй половине XIX - начале XX веков. Ислам в Сибири: вызовы времени. Сборник докладов Международной научной конференции, 92-96. Омск: Омский государственный технический университет.

Загидуллин, И. К. (2000). Перепись 1897 года и татары Казанской губернии. Казань: Татарское книжное издательство.

Инструкция для производства переписи в зданиях ведомства Императорского Двора, военного и морского, а также в казенных и общественных учреждениях и заведениях, в тюрьмах и лечебных заведениях, в частных благотворительных учреждениях и в учебных заведениях, приютах и богадельнях. (1896). Москва: Министерство внутренних дел.

Кабульдинов, 3. Е. (2001). Казахи Тобольской и Томской губерний во второй половине XVIII - начале XX вв. (Историко-демогрофический аспект). Павлодар: ЭКО.

Календарь Тобольской губернии на 1897 г. (1897). Тобольск: издание Тобольской губернской типографии.

Карих, Е. В. (2004). Межэтнические отношения в Западной Сибири в проиессе ее хозяйственного освоения. XIX - начало XX в. Томск: Издательство Томского университета.

Константинова, Н. А. (2017). Участие мусульман в аграрном переселении в Восточную Сибирь на рубеже XIX - XX веков. Иркутский историко-экономический ежегодник: 2017. Байкальский государственньй университет, Региональный центр научных исследований экономической истории России, 419-421. Иркутск: Байкальский государственный университет.

Литвинов, В. П. (2015). О высылке «вредных» мусульман из царского Туркестана (по архивным материалам). Вестник Кыргызско-Российского Славянского университета, 15(6), 73-77. 
Лысенко, Ю. А. (2010). Миссионерство Русской православной церкви в Казахстане (вторая половина XIX - начало XX в.). Барнаул: Издательство Алтайского государственного университета.

Машарипова, А. Х. (2013). Коми переселенцы в Тарском уезде Тобольской губернии в конце XIX - начале XX в. Вестник археологии, антропологии и этнографии, (2), 105-110.

Миронов, Б. Н. (2012). Город Из Деревни: Четыреста Лет Российской Урбанизации. Отечественные Записки, (3), 259-276.

Наумова, Н. И. (2005). Этнокультурное многообразие Томска (1918-1920 гг.). Судьба регионального центра в России (к 400-летию г. Томска). Сер. «Труды Томского государственного университета. Серия Историческая», 120-123.

Обзор Томской губернии за 1896 год. (1897). Томск: Губернская типография.

Общий свод по Империи результатов разработки, данных первой всеобщей переписи населения, произведенной 28 января 1897 года (Т. 2). (1905). Санкт-Петербург.

Патканов, С. К. (1912). Статистические данные, показывающие племенной состав населения Сибири, язык и роды инородиев (на основании данных спещиальной разработки материала переписи 1897 г.) (Том 1: Сводные таблицы и краткие выводы). Санкт-Петербург: Типография «Ш. Буссель».

Первая Всеобщая перепись населения Российской империи 1897 г. (1905). Санкт-Петербург: LXXVIII (78) Тобольская губерния.

Перинов, В. В. (2009). Мусульманская община Верхнеудинска в конце XIX - начале XX века: Социальный портрет. Вестник Бурятского государственного универcumema, (7), 3-9.

Распределение населения по видам главных занятий и возрастным группам по отдельным территориальным районам. (1905). Санкт-Петербург.

Скубневский, В. А., \& Гончаров, Ю. М. (2014). Города Западной Сибири во второй половине XIX - начале XX в.: Население. Экономика. Застройка и благоустройство. Барнаул: Алтайский государственный университет.

Старостин, А. Н. (2019). Формирование мусульманских общин в горнозаводских поселениях Урала и Сибири в конце XIX - начале XX в. Известия Уральского государственного горного университета, (2), 173-180.

Старостин, А. Н., \& Павлинова, Р. Н. (2016). Мечети и имамы Восточной Сибири и Дальнего Востока России в конце XIX - начале XX века: Попытка социоисторического анализа. Ислам в Сибири: вызовы времени. Сборник докладов Международной научной конференщии, 63-69. Омск: Омский государственный технический университет.

Тычинских, 3. А. (2017). Татарское купечество в Тобольской губернии в XIX - начале XX в. Исторические, философские, политические и юридические науки, культурология и искусствоведение. Вопросы теории и практики, (12-3), 196-198.

Хизриева, Г. (2008). Сообщества Мусульман в Западной Сибири. Россия и мусульманский мир, (10), 35-44. 
Шайдуров, В.Н.(2014). Евреи и их место в хозяйственной жизни Западной Сибири во второй половине XIX в. Новый исторический вестник, (1), 21-35.

Шерстова, Л. И. (2000). Влияние государственной политики на этнические процессы в Южной Сибири в первой половине XIX в. Этнографическое обозрение, (4), 102-108.

Шерстова, Л. И. (2005). Тюрки и русские в Южной Сибири: Этнополитические процессы и этнокультурная динамика XVII - начала XX века. Новосибирск: Институт археологии и этнографии Сибирского отделения РАН.

Ярков, А. П. (2012). Островок «городской культуры» в «океане» номадизма (о месте Ишима в трансформационных процессах конца XVIII - середины XIX вв.). Художественная жизнь Ииима и Приишимья. Материаль научно-практической конференции, 60-64. Ишим: Издательство Тюменского государственного университета.

Ярков, А. П. (2014). Ислам в жизни тюркского населения Западной Сибири северного Казахстана в XVII- XIX вв. История, экономика и культура средневековых тюрко-татарских государств Западной Сибири. Материалы II Всероссийской научной конференции, 132-136. Курган: Курганский государственный университет.

\section{References}

Bobitsky, A. V. (2017). Muslims of Yekaterinburg district in the materials of the first general census of the Russian Empire in 1897. Step into Historical Science, 25-27. Yekaterinburg: Ural State Pedagogical University. (In Russian).

Briukhanova, E. A., Ivanov, D. N., Nezhentseva, N. V., \& Chekryzhova, O. I. (2021). The Population of Siberian Cities at the Turn of the 19th - 20th Centuries. Based on the First All-Russian Population Census of 1897. Retrieved from https://person1897.histcensus.asu.ru/ (In Russian).

Bryukhanova, E. A. (2019). The 1897 Census: Finding "Lost" Materials and Their Preliminary Analysis. Proceedings of the Ural Federal University. Series 2, Humanities, 21(3), 152167. doi: 10.15826/izv2.2019.21.3.053 (In Russian).

Bryukhanova, E., \& Vladimirov, V. (2017). Urban occupations in a siberian city (Tobolsk, 1897). Quaestio Rossica, 5(1), 56-73. doi: 10.15826/qr.2017.1.210

Calendar of Tobolsk Province for 1897. (1897). Tobolsk: Tobolsk Province Printing House Publishing House. (In Russian).

Dashkovsky, P. K. (Ed.). (2014). The Religious Landscape of Western Siberia and Adjacent Regions of Central Asia. Barnaul: Altai State University Press. (In Russian).

Dashkovsky, P. K., \& Shershneva, E. A. (2016). On the Relationship between the Russian Orthodox Church and Muslims in Western Siberia in the Second Half of the 19th and Early 20th Centuries. Islam in Siberia: Challenges of Time. Collection of Reports of the International Scientific Conference, 92-96. Omsk: Omsk State Technical University. (In Russian). 
Distribution of population by type of main occupation and age groups in individual territorial areas. (1905). St. Petersburg. (In Russian).

First General Population Census of the Russian Empire in 1897. (1905). St. Petersburg: LXXVIII (78) Tobolsk Province. (In Russian).

General summary for the Empire of the results of the development of the first general census of the population, carried out on fanuary 28, 1897 (Vol. 2). (1905). St. Petersburg. (In Russian).

Gostyusheva, E. M., \& Dolzhikov, V. A. (2019). The Confessional Composition of the Population of Tomsk Province According to the First All-Russian Census of 1897. Bulletin of Tomsk State University. History, (59), 12-19. doi: 10.17223/19988613/59/2 (In Russian).

Instructions for censuses in buildings of the Imperial Court, military and naval institutions, as well as in state and public institutions, prisons and medical institutions, private charitable institutions and educational institutions, asylums and almshouses. (1896). Moscow: Ministry of Internal Affairs. (In Russian).

Kabuldinov, Z. E. (2001). The Kazakhs of the Tobolsk and Tomsk provinces in the second half of the 18th and early 20th centuries. (Historical and Demographic Aspect). Pavlodar: ECO. (In Russian).

Karikh, E. V. (2004). Interethnic relations in Western Siberia in the process of its economic development. 19th - beginning of the 20th century. Tomsk: Tomsk University Press. (In Russian).

Khizrieva, G. (2008). Muslim Communities in Western Siberia. Russia and the Muslim World, (10), 35-44. (In Russian).

Konstantinova, N. A. (2017). Participation of Muslims in the agrarian resettlement to Eastern Siberia at the turn of the 19th-20th centuries. Irkutsk Historical and Economic Yearbook: 2017. Baikal State University, Regional Center for Scientific Research on Economic History of Russia, 419-421. Irkutsk: Baikal State University. (In Russian).

Litvinov, V. P. (2015). On the Expulsion of "Harmful" Muslims from Tsarist Turkestan (Based on Archive Materials). Bulletin of the Kyrgyz-Russian Slavic University, 15(6), 73-77. (In Russian).

Lysenko, Yu. (2010). Missionary work of the Russian Orthodox Church in Kazakhstan (second half of the 19th century and early 20th century). Barnaul: Altai State University Press. (In Russian).

Masharipova, A. Kh. Komi migrants in the Tarsk uyezd of the Tobolsk Province in the late 19th - early 20th century. Bulletin of Archaeology, Anthropology and Ethnography, (2), 105-110. (In Russian).

Mironov, B. N. (2012). City from the Village: Four Hundred Years of Russian Urbanization. Otechestvennye Zapiski, (3), 259-276. (In Russian).

Naumova, N. I. (2005). Ethnocultural Diversity of Tomsk (1918-1920). The Fate of the Regional Center in Russia (to the 400th Anniversary of Tomsk). Ser. "Proceedings of Tomsk State University. Series Historical”, 120-123. (In Russian). 
Patkanov, S. K. (1912). Statistical data showing the tribal composition of Siberia's population, language, and clans of foreigners (based on a special development of the 1897 census material) (Vol 1: Summary tables and brief conclusions). St. Petersburg: Printing house "Sh. Bussel". (In Russian).

Perinov, V. V. (2009). Verkhneudinsk's Muslim Community in the Late 19th and Early $20^{\text {th }}$ Centuries: A Social Portrait. Bulletin of the Buryat State University, (7), 3-9. (In Russian).

Shaidurov, V. (2017). German Industrial Enterprises in Western Siberia in the second half of the 19th century. Bylye Gody, 43(1), 162-168. doi: 10.13187/bg.2017.1.162

Shaidurov, V. N. (2014). Jews and Their Place in the Economic Life of Western Siberia in the Second Half of the 19th Century. The New Historical Herald, (1), 21-35. (In Russian).

Shaidurov, V. N. (2018). The Polish community in Western Siberia: Adaption and integration features in the second half of the 19th century. Acta Histriae, 26(2), 641-660. doi: 10.19233/AH.2018.26

Sherstova, L. I. (2000). The influence of state policy on ethnic processes in South Siberia at the first half of the 19th century. Ethnographic Review, (4), 102-108. (In Russian).

Sherstova, L. I. (2005). Turks and Russians in South Siberia: Ethnopolitical Processes and Ethnocultural Dynamics in the Seventeenth and Early Twentieth Centuries. Novosibirsk: Institute of Archaeology and Ethnography, Siberian Branch of RAS. (In Russian).

Skubnevsky, V. A., \& Goncharov, Y. M. (2014). Cities of Western Siberia in the second half of the 19th century and the beginning of the 20th century: Population. Economy. Construction and improvement. Barnaul: Altai State University. (In Russian).

Starostin, A. N. (2019). The Formation of Muslim Communities in Mining and Zavodskie Settlements in the Urals and Siberia at the End of the 19th and the Beginning of the 20th Centuries. Proceedings of the Ural State Mining University, (2), 173-180. (In Russian).

Starostin, A. N., \& Pavlinova, R. N. (2016). Mosques and Imams in Eastern Siberia and the Russian Far East in the Late 19th and Early 20th Centuries: An Attempt at a SocioHistorical Analysis. Islam in Siberia: Challenges of Time. Collection of Reports of the International Scientific Conference, 63-69. Omsk: Omsk State Technical University. (In Russian).

State Budgetary Institution of the Tyumen Region "Tobolsk State Archives”. (1897a). F. I 417. In. 2. C. 13. (In Russian).

State Budgetary Institution of the Tyumen Region "Tobolsk State Archives”. (1897b). F. I 417. In. 2. C. 19. (In Russian).

State Budgetary Institution of the Tyumen Region “Tobolsk State Archives”. (1897c). F. I 417. In. 2. C. 1932. (In Russian).

State Budgetary Institution of the Tyumen Region “Tobolsk State Archives”. (1897d). F. I 417. In. 2. C. 2530. (In Russian).

State Budgetary Institution of the Tyumen Region "Tobolsk State Archives". (1897e). F. I 417. In. 2. C. 3660. (In Russian). 
Tomsk Province Survey for 1896. (1897). Tomsk: Governor's Printing House. (In Russian).

Tychinskikh, Z. A. (2017). Tatar Merchants in Tobolsk Province in the 19th and early 20th centuries. Historical, philosophical, political and legal sciences, culture and art history. Questions of theory and practice, (12-3), 196-198. (In Russian).

Yarkov, A. P. (2012). An island of "urban culture" in the "ocean" of nomadism (about the place of Ishim in the transformation processes of the late 18th - mid 19th centuries). Artistic Life of Ishim and Priishim. materials of the scientific and practical conference, 60-64. Ishim: Tyumen State University Press. (In Russian). (In Russian).

Yarkov, A. P. (2014). Islam in the life of the Turkic population of Western Siberia in northern Kazakhstan in the 17th-19th centuries. History, Economics, and Culture of the Medieval Turkic-Tatar States of Western Siberia. Proceedings of the II All-Russian Scientific Conference, 132-136. Kurgan: Kurgan State University. (In Russian).

Zagidullin, I. K. (2000). Census of 1897 and the Tatars of Kazan Province. Kazan: Tatar Book Publishers. (In Russian). 